\title{
Effective microorganisms inoculant: Diversity and effect on the germination of palisade grass seeds
}

\author{
LIDIANE F. DOS SANTOS, ROGÉRIO P. LANA, MARLIANE C.S. DA SILVA, \\ TOMÁS G.R. VELOSO, MARIA CATARINA M. KASUYA \& KARINA G. RIBEIRO
}

\begin{abstract}
Effective microorganisms (EM) are inoculants formed by fungi and bacteria isolated from soil. EM are commonly used by farmers on agronomic crops to stimulate plant growth, but their composition and their benefits has been controverted. This study aimed to analyze the diversity of microorganisms growing in three EM inoculants, as well as to evaluate their efficiency in the germination of palisade grass seeds. The total DNA of the three EM inoculants was extracted, the 16S rRNA and ITS genes were amplified by PCR and sequenced on the Illumina MiSeq platform. Germination tests were conducted with three type of the $\mathrm{EM}$, in three concentration and two times of the immersion. The bacterial group was the most abundant in EM, followed by fungi. Bacterial operational taxonomic units OTUs were shared by all EMs. Pre-treatments of palisade grass seeds with EMs resulted in a higher germination percentage (\% G) and germination speed index (IVG) when EM was used at concentration of 1 or $2 \%$ in water. Seed immersion for 5 min was more efficient than immersion for $24 \mathrm{~h}$. We can conclude that EM of different origin can share microbial groups and diversity of microorganisms, besides being an alternative to increase palisade grass seeds germination.
\end{abstract}

Key words: diversity, dormancy, sequencing, sulfuric acid.

\section{INTRODUCTION}

New technologies have been developed to increase agricultural production. However, some, including the use of mineral fertilizers and agrochemicals, have high costs and adverse effects on the environment. Agroecology is emerging as a science with the potential to redesign more sustainable agroecosystems and to increase the role of microbiological agents in the soil (Altieri 2002).

Among the microorganisms with potential to help to increase agricultural production in terms of efficacy, environmental compatibility and cost-effectiveness, are Effective Microorganisms (EM), inoculants formed by fungi and bacteria isolated from soil and capable of coexisting in fermentative liquid medium (Higa 2000, Bonfim et al. 2011). These microorganisms were first isolated in Japan by Dr. Teruo Higa, who named them "Effective Microorganisms" (Bonfim et al. 2011), but currently, several farming families already produce their own effective microorganisms (Bonfim et al. 2011).

Research has shown that EMs can be used in both agriculture and livestock. This use is via inoculation in agronomic crops to generate favorable environments for the development of plants (Olle \& Williams 2015). The interaction of EMs with the soil-plant ecosystem promotes antagonism to pathogens, nutrient supply from the decomposition of organic substrates, soil 
microbiota balance, increase of seed germination and plant growth (Bonfim et al. 2011).

Although EM technology be used throughout several areas and countries, the composition of your microbial community is still unknown, with increasing interest in its study for the performance of several functions in the ecosystem (Mayer et al. 2010). However, the identification of EM is complex because of the diverse community and the fact that traditional techniques of controlled growth are limited (Streit \& Schmitz 2004).

In an attempt to overcome the limitations associated with cultivation traditional techniques, Approaches involving molecular biology and bioinformatics have been developed. Considering these techniques, next generation sequencing in the Illumina platform is highlighted by analysis of the total genomes of microbial communities (Pessoa Filho 2010).

Among the many uses of EMs, the ability to stimulate seed germination deserves attention, because it benefits the industry brazilian of forage seeds. In Brazil, this sector requires large production, consumption and exports, reaching 115 million hectares in pastureland, of which 67\% is occupied by palisade grass (Urochloa brizantha cv Marandu) (Cardoso et al. 2014). However, this grass has a low percentage of germination due to seed dormancy, either of mechanical origin - originating from the impermeability of the seed to gases and water - or physiological related to the presence of inhibitory substances in the germination (Bewley \& Black 1994). The consequences of this dormancy are the lack of uniformity of pastures, favoring the emergence of spontaneous plants (Cardoso et al. 2014).

Seed pre-treatment methodologies have been tested to overcome dormancy in this grass and include thermal treatments, hormones, scarification with sulfuric acid $\left(\mathrm{H}_{2} \mathrm{SO}_{4}\right)$, humic acids and artificial aging. However, some of these techniques are expensive or dangerous, making the process unfeasible, or they are time consuming, affecting the commercialization of the seeds (Cardoso et al. 2014).

Benefit of EM on the germination of palisade grass seeds is not known, but in other plant species EM effect has been observed (Faltyn \& Miszkieio 2008, Ertekin 2011, Van Tonder et al. 2014). Khan et al. (2006) showed that EM in concentrations of $1 \%$ and $2 \%$ in water improved the germination of Albizia saman seeds. In two other studies, the same authors demonstrated that low concentrations of EM (2\%) promoted maximum germination in Dalbergia sissoo (Khan et al. 2011) and Acacia auriculiformis (Khan et al. 2014) seeds. In the species of Harpagophytum procumbens, Mowa \& Maass (2012) observed $32 \%$ germination in seeds pretreated with EM, whereas seeds pretreated with sulfuric acid and water germinated at $17 \%$ and $5.3 \%$, respectively.

The objective of this work was to analyze the diversity of fungi and bacteria using Illumina MiSeq sequencing of three EM inoculants of different origins. In addition, to evaluating their efficiency in the germination of palisade grass seeds.

\section{MATERIALS AND METHODS}

The experiment was carried out at the Laboratório de Associações Micorrízicas and Laboratório de Genética Molecular de Micro-organismos at the Departamento de Microbiologia, located at the Instituto de Biotecnologia Aplicada à Agropecuária (BIOAGRO) of the Universidade Federal de Viçosa, Viçosa, Minas Gerais, Brazil.

\section{Efficient microorganism (EM) inoculants}

Three EMs from different origins were used in this study, including 1) commercial EM $\left(E M \cdot 1^{\circledR}\right)$ developed by Teruo Higa in Japan and 
commercialized in Brazil by AMBIEM LTDA; 2) EM produced in the Muriaé, MG region, by agricultural families (EM2); and 3) EM produced in the region of Viçosa, $M G$, also by agricultural families (EM3).

The homemade EMS, 2 and 3, were manufactured from microorganisms obtained from the Atlantic Forest, using cooked rice (700 g) placed in the soil as bait. After the capture, the rice with microorganisms were put into a bottle along with molasses $(200 \mathrm{~mL})$ and water $(1,800 \mathrm{~mL})$ and was subjected to a fermentation process. After the process ceased, the EM was ready for use (Bonfim et al. 2011). For the commercial EM, the manufacturer reported that it was composed of water, pasteurized cane molasses and natural microorganisms, without genetic alterations.

\section{DNA extraction and PCR amplification using Illumina Miseq}

For determining the fungal and bacterial diversity of the three EMs, total DNA the three samples from each EM, was extracted using the NucleoSpin ${ }^{\circledR}$ Soil Kit (Macherey-Nagel, Germany) according to the manufacturer's instructions. The samples were then subjected to PCR amplification and sequenced on the Illumina MiSeq platform.

In the amplification of the $16 \mathrm{~S}$ rRNA, region primers $515 \mathrm{~F}$ and $806 \mathrm{R}$ were used (Caporaso et al. 2012). The ITS1 region was amplified with primers ITS1f (CTTGGTCATTTAGAGGAAGTAA) (Gardes \& Bruns 1993) and ITS2 (GCTGCGTTCTTCATCGATGC) (White et al. 1990). In the amplification reaction, $10 \mu \mathrm{L}$ of $5 \mathrm{x}$ Prime HotMasterMix (MoBio Laboratories Inc. Carlsbad, CA, USA), $1 \mu \mathrm{L}$ of each primer, $1 \mu \mathrm{L}$ of the total DNA and $12 \mu \mathrm{L}$ of MoBio water for PCR were added, totaling $25 \mu \mathrm{L}$ of reaction. The $P C R$ conditions were one initial cycle of $94^{\circ} \mathrm{C}$ for $3 \mathrm{~min}, 35$ cycles of $94^{\circ} \mathrm{C}$ for
$45 \mathrm{~s}, 50{ }^{\circ} \mathrm{C}$ for $60 \mathrm{~s}, 72{ }^{\circ} \mathrm{C}$ for $90 \mathrm{~s}$ and a final extension of $72{ }^{\circ} \mathrm{C}$ for $10 \mathrm{~min}$.

Purification of the amplicons was performed using the UltraClean ${ }^{\circledR}$ PCR Clean-Up Kit (MoBio Laboratories Inc., Carlsbad, CA, USA) and the quantification utilized Qubit $^{\circledR}$ (Invitrogen by Life Technologies). Thereafter, each amplified fragment was diluted to $2 \mathrm{nM}$, denatured, and further diluted to the final concentration of 6.75 pM for Illumina MiSeq sequencing.

\section{Processing and analysis of sequencing data}

Total DNA from each EM were sent to Argonne National Laboratory for sequencing of $16 \mathrm{~S}$ and ITS regions in Illumina MiSeq 2 X 250 pb (Illumina Inc.).

The sequencing data of the $16 \mathrm{~S}$ rRNA and ITS genes generated in the Illumina MiSeq were analyzed using Microbial Ecology Software (QIIME v.1.8.0) (Caporaso et al. 2010, Bokulich et al. 2013) using workflow designed by the Brazilian Microbiome Project (Pylro et al. 2014a, b).

Only reads with quality score above 25 at Phred scale, without ambiguous base and minimum sequence length of 240 pb (for Bacteria) and $140 \mathrm{pb}$ (for Fungi) were kept for further analysis. The sequences were clustered in Operational taxonomic units (OTUs) using and the sequences annotated using the UPARSE method in Usearch 7 (Edgar 2013). Each OTU was taxonomically annotated using the SILVA database for Bacteria and UNITE database for fungi (Koljalg et al. 2014).

Using QIIME software (Lozupone et al. 2007, Caporaso et al. 2010) we also calculated the Chao, Shannon \& Simpson indexes; Good's coverage and equitability. To evaluated the number of shared OTUs between EMs Venn diagrams were constructed (http://bioinformatics.psb.ugent. be/webtools/Venn/). 


\section{Effect of EM in seed germination of palisade grass (Urochloa brizantha cv Murundu)}

The seed germination test was conducted in a completely randomized design (CRD), using the factorial scheme $3\left(E M \cdot 1{ }^{\circledR}, E M 2\right.$ and EM3) $\times 3(1 \%$ in water, $2 \%$ in water and $100 \%$ EM) $\times 2$ (5 min and $24 \mathrm{~h})+1$ positive control $\left(\mathrm{H}_{2} \mathrm{SO}_{4}\right)+2$ negative controls (water $5 \mathrm{~min}$ or $24 \mathrm{~h}$ ) and four replicates with 50 seeds each, according to Table I.

For the assembly of the experiment, all seeds of palisade grass were superficially disinfested in $70 \%(\mathrm{v} / \mathrm{v})$ ethanol solution for $30 \mathrm{~s}$ and immersed for 5 min or $24 \mathrm{~h}$ in 1 or $2 \%$ concentration of the inoculant EM and prepared with the addition of deionized water or in 100\% EM solution (Mowa \& Maass 2014). In the treatment with sulfuric acid, the seeds of palisade grass were immersed in the acid at 18\% for $15 \mathrm{~min}$ and then washed in deionized water (Mowa \& Maass 2014).

After seeds have been treated, they were put in Petri dishes with filter paper moistened with a volume of deionized water equivalent to 3 times their weight and stored at $25^{\circ} \mathrm{C}$ (Brasil 1992). Daily counts of seedlings were taken over 30 days after the test was initiated. Seeds with protrusions of the primary root of at least $5 \mathrm{~mm}$ were considered germinated.

The percentage of germination (\%G) was calculated from the daily germinated seed count (Brasil 1992) and using the formula G\% = NG $\times 100$ / NT, where "NG" is the number of germinated seeds and "NT" is the total number of seeds placed to germinate. The germination velocity index (IVG) (Maguire 1962) was calculated using the formula IVG $=(\mathrm{G} 1 / \mathrm{N} 1)+(\mathrm{G} 2 / \mathrm{N} 2)+(\mathrm{G} 3 /$ $\mathrm{N} 3)+\ldots+(\mathrm{GN} / \mathrm{NN})$, where " $\mathrm{G}$ " is the number of seeds germinated and " $\mathrm{N}$ " is the number of days resulting from the first, second and last evaluation.

\section{Statistical analyses}

The $\% \mathrm{G}$ and IVG data were subjected to variance analysis using ASSISTAT version 7.7 (Silva \& Azevedo 2016), and the treatment means were compared using the Tukey test at 5\% significance.

\section{RESULTS}

\section{Bacteria and fungi diversity}

By the Illumina MiSeq sequencing of ITS region we recovered 1,471 sequences for EM2 inoculant and 301 sequences for EM3. Due the low sequences quality of $E M \cdot 1{ }^{\circledR}$ we did not retrieved enough data to perform further analyses for fungi in this sample (Table SI - Supplementaty Material). In the other hand, for 165 rRNA gene of bacteria, 21,037 sequences were recorded in $\mathrm{EM} \cdot{ }^{\circledR}, 23,356$ in EM2 and 35,368 in EM3 (Table II, Table SII).

The group of bacteria was more diverse than fungi in the EM (Table II). Amazingly this table, the Chao index showed the same index was observed, for example EM2 and EM3 for fungi. For bacteria, the EMs with high OTU counts had high Chao indexes. The fungal Shannon index was higher in EM3. For the bacteria, EM·1 ${ }^{\circledR}$ had the largest number of species depicted, followed by EM3 and EM2. EM2 reveals lower Simpson indexes for fungi and bacteria (Table II). In the coverage values reached by most of the phylotypes, the percentage was between 99.98 and 100\%. The equitability index was higher in EM3 in the ITS region and in $\mathrm{EM} \cdot{ }^{\circledR}{ }^{\circledR}$ in the $16 \mathrm{~S}$ rRNA region.

EMs 2 and 3 did not share fungal OTUs (Fig. 1b). While among the bacteria, 17 OTUs were shared among the three EM inoculants; 6 between $E M \cdot 1{ }^{\circledR}$ and EM2; 13 between EM2 and EM3 and 4 between EM3 and EM.1 ${ }^{\circledR}$ (Fig. 1a).

Table III shows the common bacteria OTUs found in the three EMs inoculants, from different origins. 
Table I. Experimental treatments.

\begin{tabular}{|c|c|c|}
\hline Pre-treatment & Concentration & Time \\
\hline$E M \cdot 1^{\circledR}$ & $1 \%$ & $5 \mathrm{~min}$ \\
\hline$E M \cdot 1^{\circledR}$ & $1 \%$ & $24 \mathrm{~h}$ \\
\hline$E M \cdot 1^{\circledR}$ & $2 \%$ & $5 \mathrm{~min}$ \\
\hline$E M \cdot 1^{\circledR}$ & $2 \%$ & $24 \mathrm{~h}$ \\
\hline$E M \cdot 1^{\circledR}$ & $100 \%$ & $5 \mathrm{~min}$ \\
\hline$E M \cdot 1^{\circledR}$ & $100 \%$ & $24 \mathrm{~h}$ \\
\hline EM2 & $1 \%$ & $5 \mathrm{~min}$ \\
\hline EM2 & $1 \%$ & $24 \mathrm{~h}$ \\
\hline EM2 & $2 \%$ & $5 \mathrm{~min}$ \\
\hline EM2 & $2 \%$ & $24 \mathrm{~h}$ \\
\hline EM2 & $100 \%$ & $5 \mathrm{~min}$ \\
\hline EM2 & $100 \%$ & $24 \mathrm{~h}$ \\
\hline EM3 & $1 \%$ & $5 \mathrm{~min}$ \\
\hline EM3 & $1 \%$ & $24 \mathrm{~h}$ \\
\hline EM3 & $2 \%$ & $5 \mathrm{~min}$ \\
\hline EM3 & $2 \%$ & $24 \mathrm{~h}$ \\
\hline EM3 & $100 \%$ & $5 \mathrm{~min}$ \\
\hline EM3 & $100 \%$ & $24 \mathrm{~h}$ \\
\hline $\mathrm{H}_{2} \mathrm{SO}_{4}$ & $18 \%$ & $15 \mathrm{~min}$ \\
\hline $\mathrm{H}_{2} \mathrm{O}$ & $100 \%$ & $5 \mathrm{~min}$ \\
\hline $\mathrm{H}_{2} \mathrm{O}$ & $100 \%$ & $24 \mathrm{~h}$ \\
\hline
\end{tabular}

Pre-treatments: $\mathrm{EM} 1^{\circledR}$ : commercial; EM2: produced in the Muriaé/MG region by agricultural families; EM3: produced in the region of Viçosa/MG by agricultural families; $\mathrm{H}_{2} \mathrm{SO}_{4}$ : sulfuric acid; $\mathrm{H}_{2} \mathrm{O}$ : water. Concentrations: $1 \%$ : EMs diluted in water; $2 \%$ : EMs diluted in water; 100\%: pure EMs; 18\%: $\mathrm{H}_{2} \mathrm{SO}_{4}$ diluted in water. Times: $5 \mathrm{~min}$ : immersion for $5 \mathrm{~min} ; 24 \mathrm{~h}$ : immersion for $24 \mathrm{~h}$.

Table II. Total Fungi and Bacteria OTUs, richness of species, estimates of diversity and equitability.

\begin{tabular}{|c|c|c|c|c|c|c|}
\hline Fungi & OTUs $^{1}$ & $\mathrm{Chao}^{2}$ & Shannon $^{3}$ & Simpson ${ }^{4}$ & $\%$ Coverage $^{5}$ & Equitability $^{6}$ \\
\hline EM2 & 3 & 6 & 1.37 & 0.50 & 100 & 0.53 \\
\hline EM3 & 4 & 6 & 1.51 & 0.58 & 100 & 0.58 \\
\hline Bacteria & OTUs $^{1}$ & $\mathrm{Chao}^{2}$ & Shannon $^{3}$ & Simpson $^{4}$ & \%Coverage ${ }^{5}$ & Equitability $^{6}$ \\
\hline $\mathrm{EM} \cdot 1^{\circledR}$ & 62 & 63.50 & 3.48 & 0.77 & 99.99 & 0.58 \\
\hline EM2 & 83 & 85.50 & 1.65 & 0.40 & 99.98 & 0.26 \\
\hline EM3 & 56 & 59.25 & 2.47 & 0.78 & 99.99 & 0.42 \\
\hline
\end{tabular}

${ }^{1}$ Set of readings with $97 \%$ similarity. ${ }^{2}$ Estimates species richness using total OTUs. ${ }^{3}$ Estimates species richness using individual abundance. ${ }^{4}$ Estimates the likelihood of two individuals belonging to the same species. ${ }^{5}$ Estimates the total diversity sampled. ${ }^{6}$ Estimates the pattern of individual distribution among species. ${ }^{7} n / d=$ not detected. 
(a)

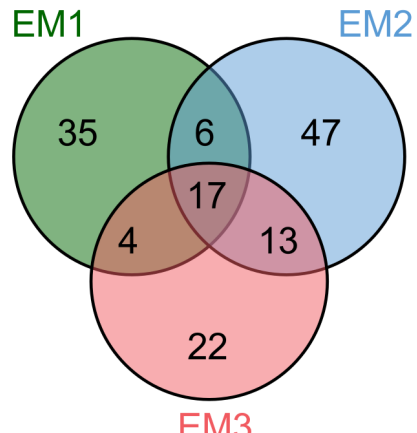

EM3 (b)

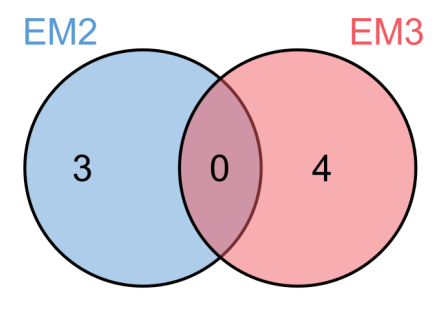

\section{Bacteria}

Fungi

Figure 1. Venn Diagram of (a) Bacteria and (b) Fungi OTUs. EM2 = Produced in the region of Muriaé; EM3 = Produced in the region of Viçosa. Within the diagram, the number represents the number of OTUs.

EM2

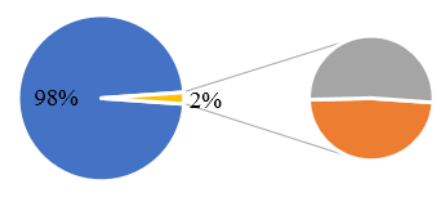

- Candida $=$ Unidentified 1 = Peniophora

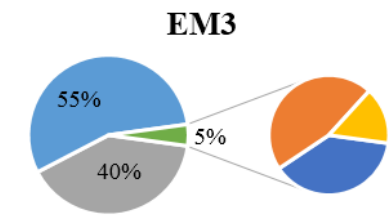

- Uwebraunia $\quad$ Penicillium

- Unidentified 2 -Fusarium

Figure 2. Distribution of OTUs of fungi genera in EM inoculants. EM2 = Produced in the region of Muriaé; EM3 = Produced in the region of Viçosa.
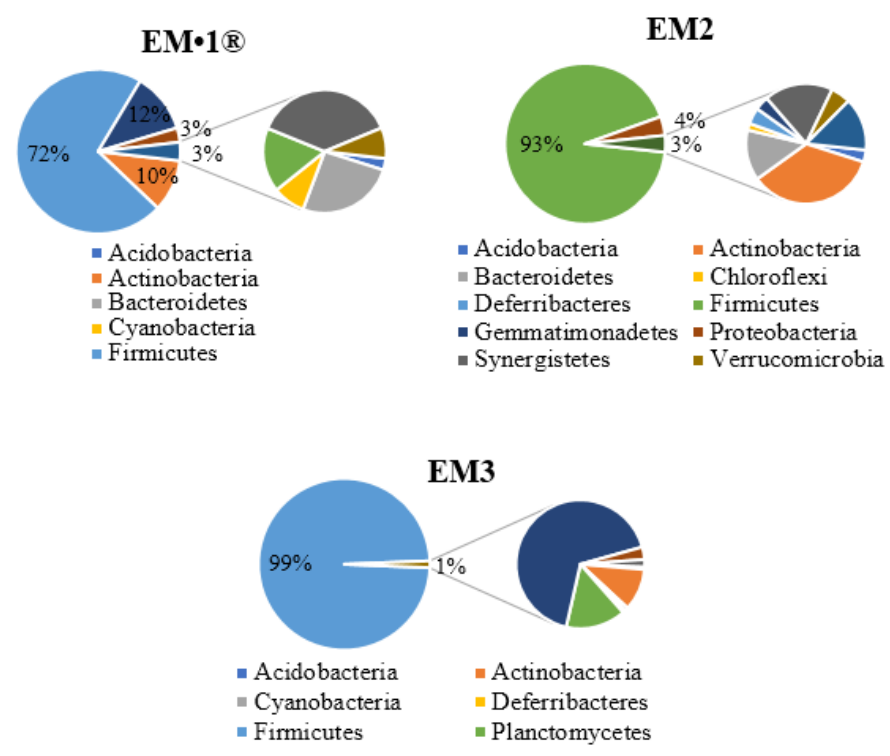

Figure 3. Distribution of OTUs of bacterial phyla in $E M$ inoculants. $E M \cdot 1^{\circledR}$ : commercial; $E M 2$ = Produced in the region of Muriaé; EM3 = Produced in the region of Viçosa. 
In the composition of the EM microbial community, it was observed that EM2 fungal OTUs were classified in two genera and in the group "Unidentified 1". The dominant genera were Candida (98\%), Peniophora (1\%) and the grouping "Unidentified 1" (1\%) (Fig. 2). In the EM3 inoculant, 55\% of the fungal OTUs were grouped and named as "Others", a group that includes OTUs whose taxonomy was not assigned. The remaining OTUs were classified into four genera, including "Unidentified 2" (40\%), Penicillium (2\%), Uwebraunia (2\%) and Fusarium (1\%) (Fig. 2).

The dominant Bacterial OTUs from EM-1 included phyla Firmicutes (72\%), Proteobacteria (12\%), Actinobacteria (10\%) and Synergistetes (3\%) (Fig. 3).

EM2 and EM3 revealed the most homogeneous profile of bacterial OTUs, evidenced by the greater abundance of the Firmicutes phylum (93\% and 99\%, respectively) in relation to the others (Fig. 3).

\section{Percentage and speed germination of palisade grass seeds}

Seeds immersed for 5 min presented the $\% \mathrm{G}$ and the IVG superior compared to the immersion for $24 \mathrm{~h}$. Regarding the EM concentrations used, the seeds soaked in 1 and $2 \%$ solutions in water presented higher values of \%G and IVG than those obtained in the immersion of seeds in pure EM. No differences in \%G and IVG among the three EMs analyzed were found $(P>0.05$; Table IV).

Inoculants at concentrations 1 or $2 \%$ in water and immersion for 5 min provided $\% \mathrm{G}$ and IVG similar to the control with sulfuric acid, but both were superior to the water control for the time of 5 min (Table V).

\section{DISCUSSION}

To our knowledge, this is the first work on the use of Illumina MiSeq sequencing in EMs from three different origins. Differences in the bacteria and fungi community among the three inoculants were observed, but some bacterial OTUs were shared. The common phyla to the three EMs included Actinobacteria, Firmicutes, Proteobacteria and Synergistetes. Within the Firmicutes phylum, the genus Lactobacillus was found, in agreement with the results obtained in the sequencing of $\mathrm{EM} \cdot 1^{\circledR}$ in Lactobacillus strains (Gaggia et al. 2013) and confirming the composition described in the literature consulted about the inoculant (Higa 2000, Bonfim et al. 2011). These lactic acid bacteria are commonly found in fermentative environments. In addition, they produce phytohormones, such as indole acetic acid (IAA) (Mohite 1993), related to promote plant growth. The genus Bacillus, also belonging to Firmicutes phylum, is very well studied for the beneficial effect on plant growth and the antagonism to phytopathogenic species, as well as producing organic acids and plant hormones (Kumar et al. 2012).

Actinobacteria are known for the ability to produce a wide variety of extracellular enzymes, proteins and phytohormones (Barka et al. 2015). Within the phylum Actinobacteria, members of the order Actinomycetales are important producers of antibiotics (Barka et al. 2015).

The phylum Proteobacteria, including order Burkholderiales, is formed by bacteria promising to the agricultural sector by the ability to produce growth regulators, siderophores and exo-heteropolysaccharide (Ring et al. 2016). In this study, we found bacteria of the family Pseudomonadaceae, phylum Proteobacteria, important in the biological control and in the production of IAA (Dharni et al. 2014). 
Fungi OTUs were not shared between EM2 and EM3. In EM2, fungi genus Candida and Peniophora were identified. According to a study by Amprayn et al. (2012), some yeasts of the genus Candida, such as Candida tropicalis HY (CtHY), have the capacity to produce IAA and, when inoculated in rice seeds, promote the best root growth.

Among the genera found in EM3, a species of the genus Penicillium, called Penicillium citrinum, is reported in the literature as able to produce gibberellins and promote plant growth, in addition to producing cellulose digestion enzymes (Khan et al. 2008). The genus Fusarium, in addition to producing IAA, synthesizes another well-characterized plant growth regulator, gibberellin, involved in the germination, growth and development of plants (Bilal et al. 2018).

The germination experiment demonstrated that pre-treatments of seeds with tested EMs inocula did not differ, indicating that any of the EMs could improve the $\% G$ and IVG. However, the efficiency of this inoculant varies according to its concentration, where the highest \%G and IVG of palisade grass seeds when treated with $1 \%$ or $2 \%$ water inoculants, which is consistent

Table III. Common bacteria OTUs found in three EM inoculants

\begin{tabular}{|c|c|c|c|c|}
\hline Phylum & Class & Order & Family & Genus \\
\hline Actinobacteria & Actinobacteria & Actinomycetales & Nocardioidaceae & - \\
\hline Actinobacteria & Actinobacteria & Actinomycetales & Nocardioidaceae & - \\
\hline Firmicutes & Bacilli & Bacillales & Bacillaceae & Bacillus \\
\hline Firmicutes & Bacilli & Bacillales & Bacillaceae & Geobacillus \\
\hline Firmicutes & Bacilli & Bacillales & Paenibacillaceae & Paenibacillus \\
\hline Firmicutes & Bacilli & Bacillales & Planococcaceae & Lysinibacillus \\
\hline Firmicutes & Bacilli & Bacillales & Staphylococcaceae & Staphylococcus \\
\hline Firmicutes & Bacilli & Bacillales & Lactobacillaceae & Lactobacillus \\
\hline Firmicutes & Bacilli & Bacillales & Clostridiaceae & Clostridium \\
\hline Proteobacteria & Betaproteobacteria & Burkholderiales & Comamonadaceae & - \\
\hline Proteobacteria & Betaproteobacteria & Burkholderiales & Comamonadaceae & - \\
\hline Proteobacteria & Epsilonproteobacteria & Campylobacterales & Campylobacteraceae & Arcobacter \\
\hline Proteobacteria & Gammaproteobacteria & Pseudomonadales & Pseudomonadaceae & - \\
\hline Proteobacteria & Gammaproteobacteria & Pseudomonadales & Pseudomonadaceae & - \\
\hline Proteobacteria & Gammaproteobacteria & Vibrionales & Pseudoalteromonadaceae & - \\
\hline Proteobacteria & Gammaproteobacteria & Xanthomonadales & Xanthomonadaceae & - \\
\hline Synergistetes & Synergistia & Synergistales & Thermovirgaceae & Thermovirga \\
\hline
\end{tabular}


with the literature, albeit in other plant species (Ertekin 2011, Khan et al. 2011, 2014, Mowa \& Maass 2012). The efficiency of EM in seed germination may be related to the degradation capacity of their coatings by the microorganisms, through enzymes produced, allowing the reception of water and oxygen and germination (Mowa \& Maass 2012).

In addition, bacteria that potentially produce phytohormones necessary for plants such as auxins, cytokinins, gibberellins and abscisic acid ( $A B A)$, which act on seed germination and other stages of plant development, and were found in all EMs analyzed, using Illumina MiSeq sequencing, like bacteria of the phylum Actinobacteria, Firmicutes and Proteobacteria.

It is hypothesized that $80 \%$ of rhizosphere bacteria may produce IAA (Loper \& Schroth 1986), in addition to other phytohormones, perhaps explaining the increase in G\% and IVG of palisade grass seeds when inoculated with
EMs, since all are produced from microorganisms captured from the environment.

On the other hand, high concentrations of EM and long periods of immersion suppressed the germination of palisade grass, as reported by Faltyn \& Miszkielo (Cardoso et al. 2014) when doubling concentration of EM when spring wheat seeds were tested. This suppression of germination may have occurred due to seed exposure to high amounts of microorganisms for a long period of time, promoting competition for nutrients between the EM and the embryo. The production of phytotoxic substances by microorganisms may also have led to the reduction of \%G and IVG. Although at first, hormones produced by microorganisms are beneficial to seed germination, in inhibitory concentrations, they can be toxic to seeds by suppressing germination, since the effects of these substances on plants are dose dependent (Carvalho et al. 2011).

Table IV. Germination percentage (\%G) and germination speed index (IVG) of palisade grass seeds treated with EM, for two immersion times and at three concentrations.

\begin{tabular}{|c|c|c|c|c|c|c|c|c|c|}
\hline & \multicolumn{2}{|c|}{ Time $^{\mathrm{1}}$} & \multicolumn{2}{|c|}{ Concentration of EM } & & \multicolumn{3}{c|}{ P value } \\
\hline Item & $5 \mathrm{~min}$ & $24 \mathrm{~h}$ & $1 \%$ & $2 \%$ & $100 \%$ & SE & Time & Conc & EM \\
\hline$\% G$ & $52.8^{\mathrm{a}}$ & $26.3^{\mathrm{b}}$ & $51.3^{\mathrm{a}}$ & $51.2^{\mathrm{a}}$ & $16.2^{\mathrm{b}}$ & 4.33 & 0.038 & 0.001 & 0.226 \\
\hline IVG & $3.65^{\mathrm{a}}$ & $1.99^{\mathrm{b}}$ & $3.89^{\mathrm{a}}$ & $3.74^{\mathrm{a}}$ & $0.83^{\mathrm{b}}$ & 0.40 & 0.013 & 0.001 & 0.263 \\
\hline
\end{tabular}

SE = standard error of the mean; Conc = concentration; means with same letters in the same line, for EM concentration and for treatment time, do not differ using the Tukey test at $5 \%$ probability. ${ }^{1}$ Each value comes from the average of 9 data points ( 3 concentrations $\times 3 \mathrm{EMs}$ ). ${ }^{2}$ Each value comes from the average of 6 data points ( 2 times $\times 3 \mathrm{EMs}$ ).

Table V. Percentage of germination (\%G) and germination speed index (IVG) of palisade grass seeds treated with sulfuric acid and EM.

\begin{tabular}{|c|c|c|c|c|c|}
\hline & \multicolumn{3}{|c|}{ Treatment } & SE & P value \\
\hline Item & Control & $\mathbf{1 8 \%} \mathbf{H}_{\mathbf{2}} \mathbf{S O}_{\mathbf{4}}$ & $\mathbf{E M}^{\mathbf{1}}$ & 3.65 & 0.002 \\
\hline$\% G$ & $39.0^{\mathrm{b}}$ & $60.0^{\mathrm{a}}$ & $64.8^{\mathrm{a}}$ & 0.42 & 0.001 \\
\hline IVG & $1.85^{\mathrm{b}}$ & $5.12^{\mathrm{a}}$ & $4.71^{\mathrm{a}}$ & 0.42 \\
\hline
\end{tabular}

$\mathrm{SE}=$ standard error of the mean; means with same letters in the same line do not differ using the Tukey test at $5 \%$ probability. ${ }^{1}$ Each value comes from the average of 6 data points (3 EMs $\times 2$ concentrations: 1 and 2\% in water, immersed for 5 min). 
The germination of palisade grass was influenced by scarification with $18 \%$ sulfuric acid, as well as by effective microorganisms, which corroborates the results found by Mowa \& Maass (2012) in the Harpagophytum procumbens species. This influence of the sulfuric acid on the palisade grass is related to the rupture provoked in the integument of the seeds, breaking dormancy and promoting germination. However, the scarification method with sulfuric acid is rarely applied on a large scale due to the care that must be taken in its use, its high cost and difficulty in acquisition (Martins et al. 2008). Thus, EM is a good alternative for increasing seed germination, considering the high diversity of potential benefit microorganisms present in EM inoculants.

\section{CONCLUSIONS}

We can conclude that EM inoculant of different origin can present different microbial composition, and share others. The use of EM can be a sustainable alternative to increase palisade grass seeds germination due to high beneficial microorganisms present in this inoculant. This is the first study to identify the diversity of bacteria and fungi in EM inoculant, and its results contribute to understanding of the effect of this inoculant on seed germination.

\section{Acknowledgments}

We would like to thank AMBIEM Ltda - BRASIL and family farmers of Muriaé and Viçosa municipalities for providing the Effective microorganisms (EM). The financial support was from Conselho Nacional de Desenvolvimento Científico e Tecnológico (CNPq), Coordenação de Aperfeiçoamento de Pessoal de Nivel Superior (CAPES) and Fundação de Amparo à Pesquisa do Estado de Minas Gerais (FAPEMIG).

\section{REFERENCES}

ALTIERI M. 2002. Bases científicas para uma agricultura sustentável. Guaíba: Agropecuária.

AMPRAYN K, ROSE MT, KECSKÉS M, PEREG L, NGUYEN HT \& KENNEDY IR. 2012. Plant growth promoting characteristics of soil yeast (Candida tropicalis HY) and its effectiveness for promoting rice growth. Appl Soil Ecol 61: 295-299.

BARKA EA, VATSA P, SANCHEZ L, GAVEAU-VAILLANT N, JACQUARD C, KLENT H, CLÉMENT C, OUHDOUCH Y \& VAN WEZEL GP. 2015. Taxonomy, physiology and natural products of Actinobacteria. Microbiol Mol Biol Rev 80: 1-43.

BEWLEY JD \& BLACK M. 1994. Seeds: physiology of development and Germination. New York: Plenum.

BILAL L, ASAF S, HAMAYUN M, GUL H, IGBAL A, ULLAH I, LEE I-J \& HUSSAIN A. 2018. Plant growth promoting endophytic fungi Aspergillus fumigatus TS1 and Fusarium proliferatum BRL1 produce gibberellins and regulates plant endogenous hormones. Symbiosis 76: 117-127.

BOKULICH NA, SUBRAMANIAN S, FAITH JJ, GEVERS D, GORDON JI, KNIGHT R, MILLS DA \& CAPORASO JG. 2013. Quality-filtering vastly improves diversity estimates from Illumina amplicon sequencing. Nat Methods 10: 57-59.

BONFIM FPG, HONÓRIO ICG, REIS IL, PEREIRA AJ \& SOUZA DB. 2011. Caderno dos microrganismos eficientes (EM): instruções práticas sobre uso ecológico e social do EM. Universidade Federal de Viçosa: Departamento de Fitotecnia, 32p.

BRASIL. REGRAS PARA ANÁLISES DE SEMENTES. 1992. Ministério da Agricultura e Reforma Agrária. Brasília: CLAV/DNDV; SNAD/MA.

CAPORASO JG ET AL. 2010. QIIME allows analysis of highthroughput community sequencing data. Nat Methods 7: 335-336.

CAPORASO JG ET AL. 2012. Ultra-high-throughput microbial community analysis on the HiSeq and MiSeq platforms. ISME J 6: 1621-1624.

CARDOSO ED, SÁ ME, HAGA KI, BINOTTI FFS, NOGUEIRA DC \& VALÉRIO FILHO WV. 2014. Desempenho fisiológico e superação de dormência em sementes de Brachiaria brizantha submetidas a tratamento químico e envelhecimento artificial. Semina: Ciênc Agrár 35: 21-38.

CARVALHO DDC, OLIVEIRA DF, CAMPOS VP \& PASQUAL M. 2011. Selection of phytotoxin producing rhizobacteria. An Acad Bras Cienc 83: 1678-2690.

DHARNI S, SRIVASTAVA AK, SAMAD A \& PATRA DD. 2014. Impact of plant growth promoting Pseudomonas 
monteilii PsF84 and Pseudomonas plecoglossicida PSF610 on metal uptake and production of secondary metabolite (monoterpenes) by rose-scented geranium (Pelargonium graveolens cv. bourbon) grown on tannery sludge amended soil. Chemosphere 9: 117-433.

EDGAR RC. 2013. UPARSE: highly accurate OTU sequences from microbial amplicon reads. Nat Methods 10: 996-998.

ERTEKIN M. 2011. Effects of microorganisms, hormone treatment and stratification on seed germination of the golden rain tree (Koelreuteria paniculata). Int J Agric Biol 13: 38-42.

FALTYN U \& MISZKIEIO T. 2008. The influence of effective microorganism on germinability of dressed spring wheat seeds. Zeszyty Naukowe Uniwersytetu Przyrodniczego we Wrocławiu 92: 31-35.

GAGGIA F, BAFFONI L, GIOIA DD, ACCORSI M, BOSI S, MAROTTI I, BIAVATI B \& DINELLI G. 2013. Inoculation with microorganisms of Lolium perenne L.: evaluation of plant growth parameters and endophytic colonization of roots. N Biotechnol 30: 695-704.

GARDES M \& BRUNS TD. 1993. ITS primers with enhanced specificity for basidiomycetes, application to the identification of mycorrihiza and rusts. Mol Ecol 2: $113-118$.

HIGA T. 2000. What is EM technology? EM World Journal 1: $1-6$.

KHAN BM, HOSSAIN MK \& MRIDHA MAU. 2006. Effect of microbial inoculants on Albizia saman germination and seedling growth. J For Res 17: 99-102.

KHAN BM, HOSSAIN MK \& MRIDHA MAU. 2011. Nursery practice on seed germination and seedling growth of Dalbergia sissoo using beneficial microbial inoculants. J For Res 22: 189-192.

KHAN BM, HOSSAIN MK \& MRIDHA MAU. 2014. Improving Acacia auriculiformis seedlings using microbial inoculant (Beneficial Microorganisms). J For Res 25: 359-364.

KHAN SA ET AL. 2008. Plant growth promotion and Penicillium citrinum. BMC Microbiol 8: 231.

KOLJALG U ET AL. 2014. Towards a unified paradigm for sequence-based identification of fungi. Mol Ecol 22: 5271-5277.

KUMAR P, DUBEY RC \& MAHESHWARI DK. 2012. Bacillus strains isolated from rhizosphere showed plant growth promoting and antagonistic activity against phytopathogens. Microbiol Res 167: 493-499.
LOPER JE \& SCHROTH MN. 1986. Influence of bacterial sources of indole-3-acetic acid on root elongation of sugar beet. Phytopathology 76: 386-389.

LOZUPONE CA, HAMADY M, KELLEY ST \& KNIGHT R. 2007. Quantitative and qualitative $\beta$-diversity measures lead to different insights into factors that structure microbial communities. Appl Environ Microbiol 73: 1576-1585.

MAGUIRE JD. 1962. Speed of germination aid in selection and evaluation for seedling emergence and vigor. crop Sci 2: 176-177.

MARTINS CC, CAMARA ATR, MACHADO CG \& NAKAGAWA J. 2008. Métodos de superação de dormência de sementes de barbatimão. Acta Sci Agron 30: 381-385.

MAYER J, SCHEID S, WIDMER F, FLIEßBACH A \& OBERHOLZER HR. 2010. How effective are 'Effective microorganisms ${ }^{\circledR}$ (EM)'? Results from a field study in temperate climate. Appl Soil Ecol 46: 230-239.

MOHITE B. 2013. Isolation and characterization of indole acetic acid (IAA) producing bacteria from rhizospheric soil and its effect on plant growth. J Soil Sci Plant Nut 13: 638-649.

MOWA E \& MAASS E. 2012. The effect of sulphuric acid and effective micro-organisms on the seed germination of Harpagophytum procumbens (devil's claw). S Afr J Bot 83: 193-199.

OLLE M \& WILLIAMS I. 2015. The Influence of Effective Microorganisms on the Growth and Nitrate Content of Vegetable Transplants. J Adv Agric 2: 25-28.

PESSOA FILHO MACP. 2010. Metagenômica e sua aplicação no estudo de diversidade e função de microrganismos de solos do Cerrado. Planaltina: Embrapa Cerrados.

PYLRO VS, ROESCH LFW, MORAIS DK, CLARK IM, HIRSCH PR \& TÓTOLA MR. 2014a. Data analysis for 16S microbial profiling from different benchtop sequencing platforms. J Microbiol Methods 107: 30-37.

PYLRO VS ET AL. 2014b. Brazilian Microbiome Project: revealing the unexplored microbial diversity - challenges and prospects. Microb Ecol 67: 237-241.

RING HJB, ZENTELLA, LMC \& SIERRA LGT. 2016. Burkholderia tropica una bacteria con gran potencial para su uso en la agricultura. Revista Especializada en Ciencias QuímicoBiológicas 19: 102-108.

SILVA FAZ \& AZEVEDO CAV. 2016. The Assistat Software Version 7.7 and its use in the analysis of experimental data. Afr J Agric Res 11: 3733-3740.

STREIT WR \& SCHMITZ RA. 2004. Metagenomics-the key to the uncultured microbes. Curr Opin Microbiol 7: 492-498. 
VAN TONDER NCP, VAN DER WESTHUIZEN C \& VAN DER WESTHUIZEN RJ. 2014. Interaction effects of Effective Microorganisms and prolonged storage on germination and seedling vigour of maize, sorghum and sunflower. JNGS 12: 147-161.

WHITE TJ, BRUNS S, LEE S \& TAYLOR J. 1990. Amplification and direct sequencing of fungal ribosomal RNA genes for phylogenetics. PCR Protocols: A Guide to Methods and Applications 38: 315-322.

\section{SUPPLEMENTARY MATERIAL}

Table SI. OTUs of fungi present in EM· $1^{\circledR}, E M 2$ and $E M 3$. Table SII. OTUs of bacteria present in $E M \cdot 1^{\circledR}, E M 2$ and EM3.

\section{How to cite:}

SANTOS LF, LANA RP, SILVA MCS, VELOSO TGR, KASUYA MCM \& RIBEIRO KG. 2020. Effective microorganisms inoculant: Diversity and effect on the germination of palisade grass seeds. An Acad Bras Cienc 92: e20180426. DOI 10.1590/0001-3765202020180426.

Manuscript received on April 4, 2018; accepted

for publication on December 28, 2018

LIDIANE F. DOS SANTOS ${ }^{1}$

https://orcid.org/0000-0002-8429-6552

\section{ROGÉRIO P. LANA ${ }^{2}$}

https://orcid.org/0000-0001-5200-9005

\section{MARLIANE C.S. DA SILVA}

https://orcid.org/0000-0003-4678-7876

\section{TOMÁS G.R. VELOSO}

https://orcid.org/0000-0001-6874-8208

\section{MARIA CATARINA M. KASUYA}

https://orcid.org/0000-0002-9539-9370

\section{KARINA G. RIBEIRO ${ }^{2}$}

https://orcid.org/0000-0002-1299-2807

${ }^{1}$ Departamento de Agroecologia, Universidade Federal de Viçosa, Av. Peter Henry Rolfs, s/n, 36571-000 Viçosa, MG, Brazil

${ }^{2}$ Departamento de Zootecnia, Universidade Federal de Viçosa, Av. Peter Henry Rolfs, s/n, 36571-000 Viçosa, MG, Brazil

${ }^{3}$ Departamento de Microbiologia, Universidade Federal de Viçosa, Av. Peter Henry Rolfs, s/n, 36571-000 Viçosa, MG, Brazil
Correspondence to: Maria Catarina Megumi Kasuya, Lidiane Figueiredo dos Santos

E-mail:mksuya@ufv.br, lidianefigueiredosantos@hotmail.com

\section{Author contributions}

Conceived and designed the experiments: LFS, RPL, MCSS, MCMK, KGR. Performed the experiments: LFS, MCSS. Analyzed the data: LFS, RPL, MCSS, TGRV, MCMK. Contributed reagents/materials/analysis tools: MCMK. Wrote the paper: LFS, RPL, MCSS, MCMK, KGR.

\section{(cc) BY}

